\title{
Research
}

\section{A Diagnostic Procedure for Transformative Change Based on Transitions, Resilience, and Institutional Thinking}

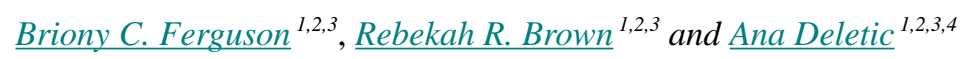

\begin{abstract}
Urban water governance regimes around the world have traditionally planned large-scale, centralized infrastructure systems that aim to control variables and reduce uncertainties. There is growing sectoral awareness that a transition toward sustainable alternatives is necessary if systems are to meet society's future water needs in the context of drivers such as climate change and variability, demographic changes, environmental degradation, and resource scarcity. However, there is minimal understanding of how the urban water sector should operationalize its strategic planning for such change to facilitate the transition to a sustainable water future. We have integrated concepts from transitions, resilience, and institutional theory to develop a diagnostic procedure for revealing insights into which types of strategic action are most likely to influence the direction and pace of change in the overall system toward a desired trajectory. The procedure used the multipattern approach, from transition theory, to identify the system conditions and type of changes necessary for enabling system transformation. It incorporated the adaptive cycle, from resilience theory, to identify the current phase of change for different parts of the system. Finally, it drew on the concepts of institutional pillars and institutional work to identify mechanisms that are likely to be most effective in influencing the transformative dynamics of the system toward a desired trajectory. We have demonstrated application of the proposed diagnostic procedure on a case study of recent transformative change in the urban water system of Melbourne, Australia. We have proposed that an operational diagnostic procedure provides a useful platform from which planners, policy analysts, and decision makers could follow a process of deduction that identifies which types of strategic action best fit the current system conditions.
\end{abstract}

Key Words: institutions; resilience; strategic planning; sustainability; transformative change; transition; urban water

\section{INTRODUCTION}

Governance regimes in urban water sectors around the world have traditionally planned large-scale, centralized infrastructure systems that aim to control variables, e.g., supply and demand, and reduce uncertainties. However, climate change and variability, demographic changes, environmental degradation, and resource scarcity mean that future social-ecological drivers will not be addressed by this conventional approach. The increasing awareness of this uncertain future context and the need to transition toward sustainable alternatives in a range of infrastructure sectors, e.g., energy supply and transport, is reflected by the growth of research focused on the challenge of escaping locked-in path dependencies of large-scale sociotechnical systems (e.g., Berkhout 2002, Frantzeskaki and Loorbach 2010, Truffer et al. 2010, Farrelly and Brown 2011). However, there is minimal scholarly or practical understanding of how sectors should make planning and policy making operational to enable a transition to a sustainable and resilient future (e.g., Smit and Wandel 2006, Dolata 2009, Chapin et al. 2010).

A transition, or transformative change, refers to the fundamental system-wide change in the structure and functioning of a system. For urban water systems, transformative change means a radical shift in how water servicing is planned, designed, constructed, operated, managed, governed, and valued. Insights into patterns of dynamic transformative change would be invaluable for identifying which types of strategic action best fit the current conditions of an urban water system so that governance actors are better equipped to address current and future water management challenges. However, scholars have argued that the links between policy, strategy, and action and the complex dynamics of transformative change are underdeveloped, from both a theoretical and an empirical research perspective (e.g., Geels 2004, Elzen and Wieczorek 2005, Chapin et al. 2010). This highlights gaps in the scholarship of strategic planning in relation to systemic change, which are reflected by how planning is undertaken in practice. Dominguez et al. (2009) note that there is growing awareness of the need for improved planning of infrastructure systems and that a range of approaches are being developed, including participatory methods, analytic frameworks, and computer simulations. However, strategic planning tools are typically developed, implemented, or evaluated from a paradigm of incremental linear change, based on the assumption that strategic actions can be designed through analysis of simple "cause-and-effect" mechanisms (Truffer et al. 2010). Instead, infrastructural systems should be understood through a systems perspective 
that embraces uncertainty and complexity over the long term and facilitates planning for nonlinear change (Foxon et al. 2009, de Graaf and van der Brugge 2010, Truffer et al. 2010).

Tools to inform strategic planning in a complex infrastructural system, such as urban water, should address important questions related to nonlinear systemic change over long time frames, i.e., in the order of decades. For example, how should current planning be designed to address future system needs? When is the potential for transformative change likely to occur? What is the system's current phase of change? How should the system prepare for transformative change? What types of strategic initiatives are likely to be most effective for the current conditions? How are feedback loops in the system likely to impact on the efficacy of planned strategic action? What interventions are likely to be effective in the long term, given the uncertain and nonlinear future contexts? These types of questions highlight limitations of existing approaches for selecting and designing strategic initiatives, and although some planning approaches could be applied within a systems paradigm, there is an absence of conceptual tools for use in critically informing strategic planning from the perspective of dynamic transformative change (Walker et al. 2006, Chapin et al. 2010, van de Meene et al. 2011). This absence may be because planning initiatives tend to be undertaken within a time frame that reflects short-term electoral cycles, whereas strategic action for transformative change would likely be, whereas strategic action for transformative change would be likely based on a much longer-term view, perhaps in the order of 20-50 years, which presents a range of pragmatic challenges.

Recent literature argues the need to avoid panaceas in planning and managing integrated systems, instead proposing that diagnostic approaches are a better alternative (e.g., Ostrom 2007, 2009, Pahl-Wostl 2009, Cox 2011). We therefore propose that the previous questions for strategic planning could be addressed effectively if initiatives were guided by the use of a diagnostic procedure that can determine the potential transformative capacity of a system and therefore identify which types of strategic action best fit the current system. Such a procedure would enable strategic planners and decision makers to identify opportunities for strategic initiatives that are likely to fundamentally change practices and enable the transition to sustainability. As such, we aim to develop a diagnostic procedure for revealing insights into which types of strategic action are most likely to influence the direction and pace of change in an urban water system toward a desired trajectory.

Ferguson et al. (2013) outline a scope for the design of an operational diagnostic procedure that maps a system's current conditions and identifies its potential transformative capacity, suggesting that such a procedure should include the following characteristics: (1) It addresses a sequence of nested diagnostic questions (DQs) that provide retrospective analysis of a system problem or system changes. (2) It offers analytic lenses that relate to the broad system scale, individual variables, static snapshots in time, and dynamic links between system states. (3) It is capable of analyzing system variables that are actors, i.e., individuals or organizations; structures, i.e., social, ecological, or technological; processes, i.e., social or biophysical; contexts, i.e., political, economic, social, or environmental; and outcomes. (4) It incorporates a methodological framework that provides operational guidance. (5) It is underpinned by conceptual frameworks that provide a description and an explanation of a system problem or changes. (6) It is capable of predicting the impacts of strategic action on a system's dynamics. (7) It is capable of informing the selection of strategic initiatives that best fit the current system conditions.

We propose an operational diagnostic procedure for urban water systems that follows this scope and could underpin a strategic planning tool. The proposed diagnostic procedure integrates concepts from the fields of transition studies, resilience of social-ecological systems, and new institutionalism, and its application is demonstrated on a case study of recent transformative change in the urban water system of Melbourne, Australia.

We make the normative assumption that a transition to sustainable water management is necessary if the broad range of societal needs from an urban water system is to be satisfied within the context of future social-ecological drivers. Although not our focus, we acknowledge that the prospect of actively navigating a transition has been contentious in the literature. Commentators have expressed concern about a lack of focus on the political nature of managing a transition, whether it is desirable to manage a transition, and whether it is even possible to manage a transition (e.g., Elzen and Wieczorek 2005, Smith et al. 2005, Shove and Walker 2007, Genus and Coles 2008, Smith and Stirling 2010). To address these concerns in relation to the use of the operational diagnostic procedure we have proposed, we emphasize from a pragmatic stance that strategic planning for urban infrastructure is continually undertaken, regardless of the paradigm from which the planning is conducted. We therefore contend that the development and use of a diagnostic procedure for transformative change brings significant improvement over existing planning tools, which are widely accepted as having limited ability to deal with the challenges of complex, interconnected, and uncertain future contexts (Dominguez et al. 2009, Foxon et al. 2009, Truffer et al. 2010, Farrelly and Brown 2011). However, we note that all decision support tools should be applied with caution, ensuring the participation of a broad range of stakeholders and consideration of the perspectives of all relevant actors, in combination with a reliable assessment of the boundaries and limitations of the biophysical conditions of the system. 


\section{DEVELOPMENT OF A DIAGNOSTIC PROCEDURE}

\section{Theoretical background}

Two main areas of scholarship that could underpin the development of a diagnostic procedure for analyzing the dynamics of transformative change were identified: transition theory and resilience theory. These fields each aim to explore the transformative dynamics in integrated complex systems so that governance interventions are designed to achieve desirable system states in the future. Although each theory's heritage lies in diverse research fields and their perspectives sometimes appear to conflict, there are many parallels in how they understand the nature of complex adaptive systems and conceptualize system transformations. Until recently, the two theories, and hence scholarly activity, have remained separate; however, researchers are now considering ways in which each can provide insight and strengthen overall understanding of transformative change and implications for governance (e.g., van der Brugge and van Raak 2007, Foxon et al. 2009, Smith and Stirling 2010). Table 1 synthesizes key insights for how each theory explains different dimensions of transformative change in an integrated system.

The synthesized understandings about transformative change, described in Table 1, highlight the parallel concepts shared by transition theory and resilience theory. This common base means that there is the potential to integrate concepts from both transitions and resilience thinking to develop a diagnostic procedure for analyzing transformative dynamics.

A diagnostic procedure for guiding strategic action requires conceptual links with how actors can influence a system. Although the transitions and resilience literature acknowledges the fundamental role of actors in shaping a system, it lacks operational tools for analyzing how transformative change can be enabled through actor strategies (Farla et al. 2012, Brown et al. 2013). Ferguson et al. (2013) identify that the functionality of urban water systems is predominately influenced by actors' implicit and explicit decisions about material elements, such as technology and infrastructure. In this sense, change in the biophysical dimensions of a socio-technical system is achieved through change in the social dimensions. The proposed diagnostic procedure therefore takes the concept of institutional change as the entry point for how transitions can be deliberately induced and navigated by actors, while acknowledging that there would be a lag time in observations of corresponding changes in technology or infrastructure.

New institutionalism is a research field that aims to offer insight into the nature of institutions and processes of institutional change, particularly by analyzing the interplay between institutions and agency (Lawrence et al. 2009). Two concepts within institutional theory are used in the diagnostic procedure to provide insight into how actors can influence the direction of transformative change in a system. The concept of institutional pillars, proposed by Scott (2008), identifies three analytic elements that comprise institutions and therefore shape the practices of actors. Regulative institutional elements are the, typically formal, social structures that are monitored and evaluated, such as rules, laws, and sanctions; informal systems of rules may also be regulative. Normative elements define the goals of a system through specifying the values, norms, and standards that are expected to be upheld within the institution. Cultural-cognitive elements encompass the common beliefs, logic, and meaning that are shared within an institution, resulting in actor behaviors and routines that often seem instinctive or taken for granted. These three institutional pillars form the underpinning social structures of a sociotechnical system.

The concept of institutional work is a recent development in institutional theory, aiming to re-emphasize the agency of actors in shaping institutions. At its foundation is Giddens's (1984) structuration theory, which perceives human action as both being constrained by social structures and reproducing social structures. The institutional work concept applies this "duality of structure" to institutions, conceptualizing that "institutions shape people's practices, but it is also people's practices that constitute and reproduce institutions" (Battilana and D'Aunno 2009:43). The idea that actors can shape institutions is at the core of institutional work, which Lawrence and Suddaby (2006) define as the purposive action of individuals and organizations aimed at creating, maintaining, and disrupting institutions. Therefore, it focuses analyses on the efforts of individual and collective actors to influence institutions, rather than on the outcomes or results (Lawrence et al. 2011). The concept builds on research within institutional theory that examines processes of institutionalization and deinstitutionalization, as well as practice theory, which delves inside processes of change to examine the intelligent, situated activities undertaken by actors (Lawrence and Suddaby 2006).

\section{Conceptual building blocks}

The multipattern approach (MPA) for analyzing transitions (de Haan 2010, de Haan and Rotmans 2011) conceptualizes that a societal, or socio-technical, system exists to meet a range of societal needs. For example, an urban water system provides a range of services to meet the need for water supply, sanitation, flood protection, and more. The way the system provides these services can shift over time in response to changing societal needs, contextual drivers, and internal stresses.

The MPA perceives that transformative change in a system can unfold in many different ways over time, depending on the dynamic mechanisms that occur. It builds on established transition concepts of the multilevel perspective and multiphase change to theoretically deduce the full range of possible transition pathways. This theoretical approach means that it can be applied to identify universal transition pathways 
Table 1. Key dimensions of transformative change.

\begin{tabular}{|c|c|c|c|}
\hline \multirow[t]{2}{*}{ Dimension } & \multirow{2}{*}{$\begin{array}{l}\text { Transitions Literature } \\
\text { E.g., Rotmans et al. 2001, Geels 2002, } \\
\text { Berkhout et al. 2004, Smith et al. 2005, 2010, } \\
\text { Geels and Schot 2007, Rotmans and } \\
\text { Loorbach 2009, de Haan and Rotmans } 2011\end{array}$} & \multirow{2}{*}{$\begin{array}{l}\text { Resilience Literature } \\
\text { E.g., Holling 1973, Berkes et al. 1998, 2003, } \\
\text { Gunderson and Holling 2002, Folke 2006, } \\
\text { Olsson et al. 2006, Walker et al. 2006, Chapin } \\
\text { et al. 2009, 2010 }\end{array}$} & \multirow{2}{*}{$\begin{array}{l}\text { Synthesized Understanding } \\
\text { Of transformative change in complex } \\
\text { urban infrastructure systems }\end{array}$} \\
\hline & & & \\
\hline $\begin{array}{l}\text { Theoretical } \\
\text { roots }\end{array}$ & $\begin{array}{l}\text { Integrated assessment, technology diffusion, } \\
\text { evolutionary economics, innovation, } \\
\text { governance. }\end{array}$ & $\begin{array}{l}\text { Ecology, social-ecological systems, } \\
\text { governance. }\end{array}$ & \\
\hline Goal & $\begin{array}{l}\text { Radically change system structures so its } \\
\text { function becomes sustainable and desirable } \\
\text { in future contexts. Sustainability goals are } \\
\text { explicitly normative. }\end{array}$ & $\begin{array}{l}\text { Maintain system function so it is ecologically } \\
\text { resilient to disturbance in the form of acute } \\
\text { shocks and chronic stress. }\end{array}$ & $\begin{array}{l}\text { Transform system structures toward vision } \\
\text { of sustainability and resilience in context } \\
\text { of uncertain future. Goal is a resilient } \\
\text { system, not a resilient regime. }\end{array}$ \\
\hline $\begin{array}{l}\text { Functional } \\
\text { scale }\end{array}$ & $\begin{array}{l}\text { Multilevel perspective distinguishes between } \\
\text { three scales of structures and processes: } \\
\text { broad landscape, dominant regimes, and } \\
\text { innovative niches. Elements of each can } \\
\text { change over time, e.g., niches can grow to } \\
\text { niche-regimes, which can eventually replace } \\
\text { regimes. Microdynamic patterns of change } \\
\text { drive overall system dynamics, i.e., niche- } \\
\text { regime-landscape interactions. }\end{array}$ & $\begin{array}{l}\text { Panarchy represents a nested hierarchy in } \\
\text { which higher levels have larger structures and } \\
\text { slower processes, while lower levels have } \\
\text { smaller structures and faster processes. } \\
\text { Elements of scale can change over time, e.g., } \\
\text { new levels can be added in a panarchy. } \\
\text { Microdynamics of change drive the overall } \\
\text { system dynamics, e.g., "revolt" and } \\
\text { "remember" functions. }\end{array}$ & $\begin{array}{l}\text { Change occurs at multiple functional } \\
\text { scales and the dynamic interactions } \\
\text { between and within scales are } \\
\text { fundamental drivers of a system } \\
\text { transformation. }\end{array}$ \\
\hline Spatial scale & $\begin{array}{l}\text { The relevance of the spatial context depends } \\
\text { on the system under consideration. }\end{array}$ & $\begin{array}{l}\text { The spatial context needs explicit } \\
\text { consideration. Spatial scales can be nested. }\end{array}$ & $\begin{array}{l}\text { Spatial dimensions provide unique } \\
\text { characteristics, potentially influencing } \\
\text { how transformative change occurs. }\end{array}$ \\
\hline Temporal scale & $\begin{array}{l}\text { Change is nonlinear and characterized by } \\
\text { punctuated equilibriums, represented by the } \\
4 \text { phases in the S-curve (predevelopment, } \\
\text { take-off, acceleration, stabilization). The } \\
\text { different phases of the S-curve each have } \\
\text { their own temporal scale. }\end{array}$ & $\begin{array}{l}\text { Change is nonlinear and characterized by } \\
\text { punctuated equilibriums, represented by the } 4 \\
\text { phases of the adaptive cycle (exploitation, } \\
\text { conservation, release, reorganization). } \\
\text { Temporal scales can be nested, with different } \\
\text { levels going through different phases at each } \\
\text { point in time. }\end{array}$ & $\begin{array}{l}\text { Transformative change is characterized by } \\
\text { punctuated equilibriums, in which phases } \\
\text { alternate between long periods of steady } \\
\text { incremental change and short periods of } \\
\text { rapid transitional change. Different } \\
\text { functional scales and phases of change } \\
\text { have different temporal scales. }\end{array}$ \\
\hline Speed & $\begin{array}{l}\text { Landscape structures and processes change } \\
\text { slowly while niche structures and processes } \\
\text { change quickly. Transitions occur over long } \\
\text { timeframes, in the order of } 25-50 \text { years. }\end{array}$ & $\begin{array}{l}\text { Different scales change at different speeds: } \\
\text { higher scales change slowly, lower scales } \\
\text { change quickly. }\end{array}$ & $\begin{array}{l}\text { Higher functional scales change slowly } \\
\text { while lower functional scales change } \\
\text { quickly. }\end{array}$ \\
\hline Timing & $\begin{array}{l}\text { Windows of opportunity are critical for } \\
\text { enabling transformative change. }\end{array}$ & $\begin{array}{l}\text { Windows of opportunity are critical for } \\
\text { enabling transformative change. System } \\
\text { response to an issue will be different at } \\
\text { different times. }\end{array}$ & $\begin{array}{l}\text { Timing is critical. The timing of strategic } \\
\text { action, in relation to windows of } \\
\text { opportunity, will influence its effects on } \\
\text { the overall system. }\end{array}$ \\
\hline Actors & $\begin{array}{l}\text { Actors are fundamental but have had } \\
\text { minimal consideration in transition literature } \\
\text { on change dynamics. }\end{array}$ & $\begin{array}{l}\text { Actors are fundamental but have had minimal } \\
\text { consideration in resilience literature on change } \\
\text { dynamics. }\end{array}$ & $\begin{array}{l}\text { Actors are fundamental but theory } \\
\text { currently lacks tools for analyzing their } \\
\text { role and implications for governance. }\end{array}$ \\
\hline
\end{tabular}

for use in "futures" research, a key gap that Genus and Coles (2008) argue exists in other transition approaches focused on pattern identification in historic empirical cases for analyzing transition pathways (e.g., Berkhout et al. 2004, Smith et al. 2005, Geels and Schot 2007).

The MPA extends the multilevel perspective's landscape, regime, and niche concepts using a complexity approach to analyze the mechanisms that drive interactions between them (de Haan and Rotmans 2011). The MPA conceptualizes the system as a set of subsystems, known as constellations. Each constellation is composed of structures, including institutions and biophysical structures such as ecosystems, infrastructures, and technologies. Actors are not part of constellations; they reside on a different conceptual layer and relate to the constellation structures via emergent processes. Individual actors can therefore have agency in multiple constellations, removing the need to distinguish between "regime actors" and "niche actors" (Fig. 1).

Constellations are defined by the function they provide in meeting different societal needs. The constellation(s) with the greatest share of functioning are the most powerful, forming a regime. The combined functioning of the regime constellation(s) dominates the overall system functioning. Constellations interact with each other and the landscape in which the system is embedded. System transformation occurs when the power balance between constellations fundamentally shifts, radically changing the underlying system structure and the way in which it functions to meet society's needs.

To explain the interactions between constellations, the MPA identifies top-down, bottom-up, and internally induced drivers 
Fig. 1. Conceptualization of the Multipattern Approach.

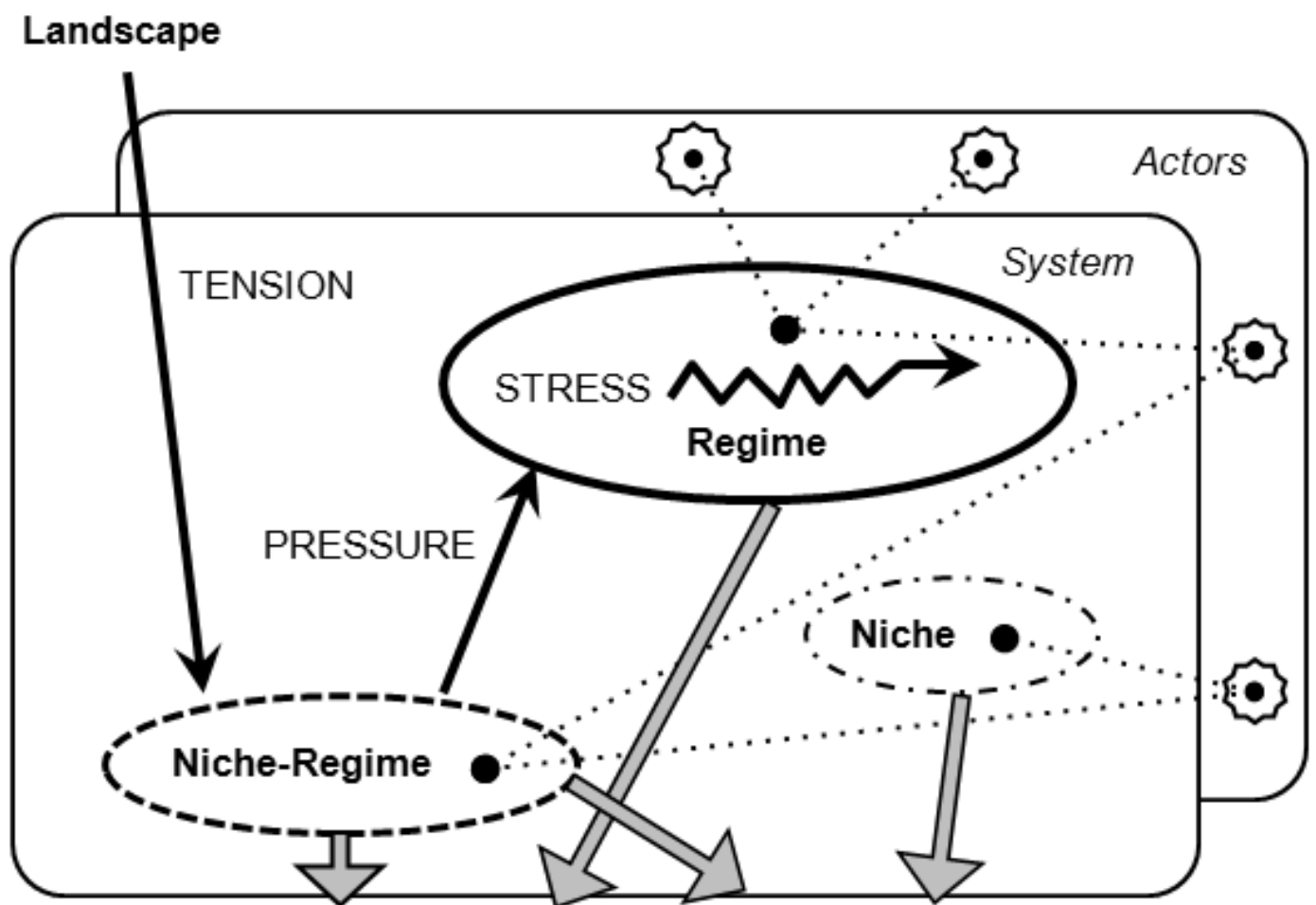

Societal Need 1

Societal Need 2

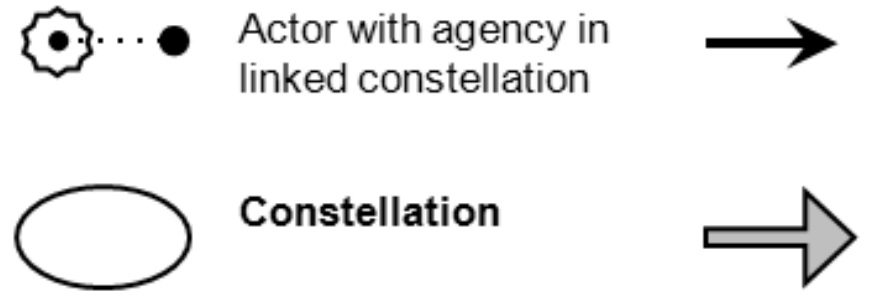

\section{CONDITIONFOR \\ TRANSITIONAL \\ CHANGE}

\section{Constellation function to meet Societal Need}

of, or conditions for, transformative change, i.e., tension, pressure, and stress (Fig. 1). These conditions drive different transition patterns: "reconstellation," or top down; "empowerment," or bottom up; and "adaptation," or internal. Over time, these transition patterns can concatenate into pathways that lead to a transition. This creates a theoretically derived typology of all possible transition pathways, dominated by one or more of the transition patterns. The transition pathway experienced within a system at a given time will depend on the power dynamics between the existing regime, upcoming niches, and landscape tensions.

The MPA shows promise in decoupling the societal mechanisms, i.e., the patterns, from what drives them, i.e., the conditions, and how they manifest in systems, i.e., the pathways. However, investigation of the potential effectiveness of particular strategic initiatives on future transitions requires insight into the likely timing and strength of conditions for change so that the impact of system interventions can be anticipated. The timing and strength of transition conditions will be significantly influenced by the dynamics of structures internal to constellations, an aspect acknowledged and speculated on in the transitions literature (e.g., Geels 2002, 2004, Geels and Schot 2007, de Haan 2010) but not dealt with from an analytic perspective (Genus and Coles 2008).

The underpinning concept of the panarchy framework in resilience theory, the adaptive cycle, is the next building block of the proposed diagnostic procedure. It is introduced to the 
Fig. 2. The adaptive cycle: (a) Dimensions and phases (adapted from Holling and Gunderson 2002); (b) Implications for policy and strategy (adapted from Gunderson et al. 2002 and Olsson et al. 2006); (c) Integration with the Multipattern Approach (de Haan and Rotmans 2011; refer Fig. 1); (d) Alignment with institutional pillars (Scott 2008) to indicate the pillar of focus for strategic action.

(a) Dimensions and phases

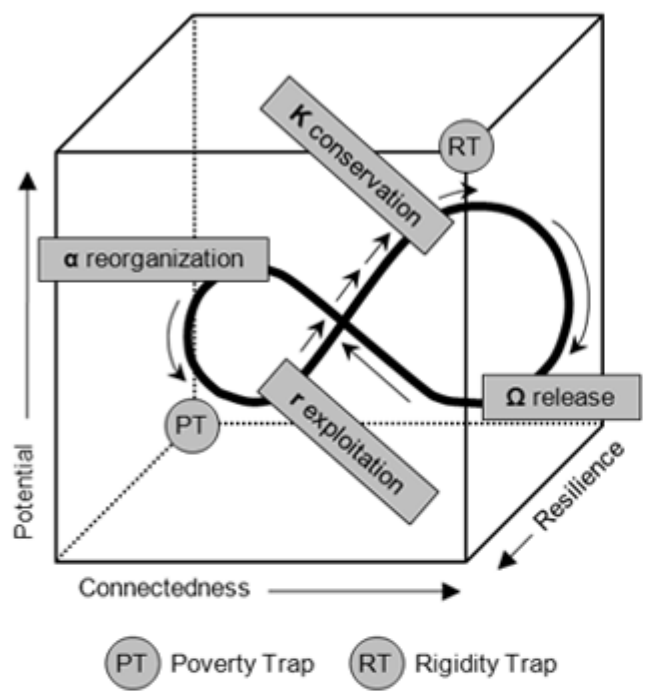

(c) Integration with the MPA

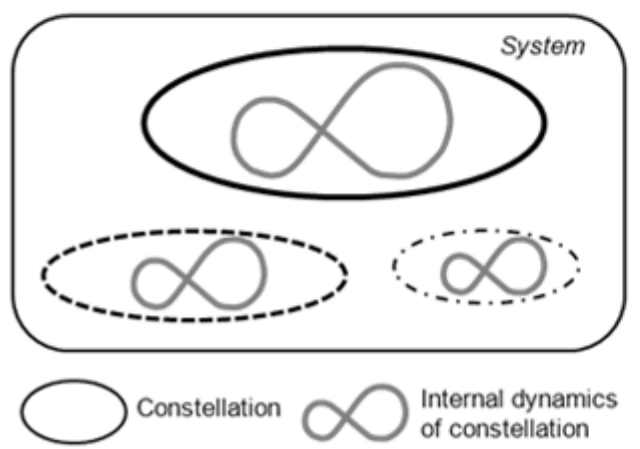

(b) Policy and strategy implications

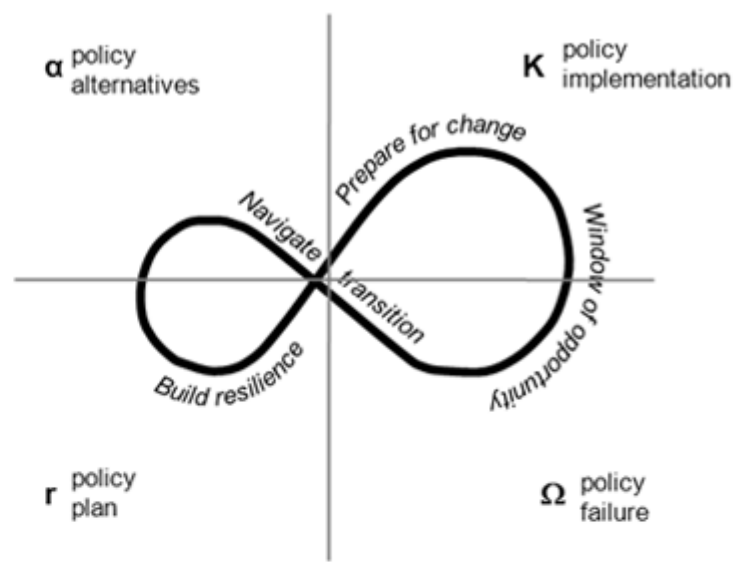

(d) Alignment with institutional pillars

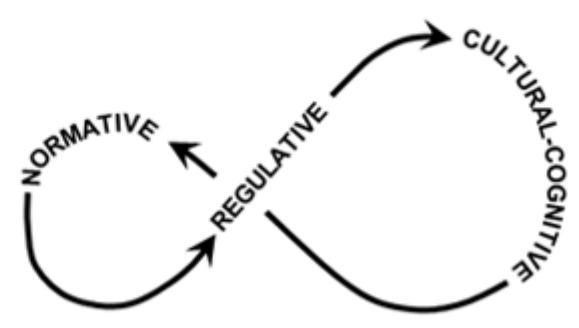

procedure to provide conceptual insight into these internal constellation dynamics. The adaptive cycle represents a fundamental unit of dynamic change. It makes a distinction between alternating phases of change in a complex system that responds to disturbances over time, cycling through periods of growth and dynamic stability and periods of change and variety (Holling and Gunderson 2002).

Three properties shape the responses of social-ecological systems to crisis and influence the future state of the system; these form the three dimensions of the adaptive cycle (Fig. 2a). The inherent potential of a system for enabling change will determine what options are possible in the future, also referred to as the "wealth" or "capital" of a system. The level of connectedness between variables will influence the degree to which the system is flexible or rigid. The resilience, or adaptive capacity, of a system will determine its vulnerability to disturbance, whether the disturbance is in the form of chronic stress or acute shocks (Smith and Stirling 2010). There are four distinct phases of an adaptive cycle (Fig. 2a); the trajectory alternates between long, slow periods of exploitation and conservation of resources, i.e., from $r$ to $K$ in the "front loop," interspersed with short periods that maximize opportunities for innovation, i.e., from $\Omega$ to $\alpha$ in the "back loop." Subsequent cycles continue along the same trajectory, with similar structures and processes, or the system enters a new cycle if innovations developed in the back loop stimulate sufficiently divergent structures and processes. If a new cycle 
is entered, transformative change is considered to have occurred in the system (Holling and Gunderson 2002).

Gaining insight into the nested adaptive cycles of a socialecological system provides an ability to identify when the system is capable of welcoming change and when it is vulnerable (Holling and Gunderson 2002). Pritchard and Sanderson (2002) argue that understanding the location of a social-ecological system within its episodic phases of the adaptive cycle is important for system management because actions that are effective at one phase of the cycle may not be suitable at another. Scholars are starting to explore how governance regimes can use the concept of adaptive capacity to deal with uncertainty and change. For example, Olsson et al. (2006) identify three phases of social-ecological system transformation that would have distinct strategies linked to them: (1) preparing for change through developing new knowledge, leadership capacity, and shadow networks; (2) navigating the transition through anticipating a window of opportunity, nurturing innovation, and maintaining flexible institutions; and (3) developing resilience of the new direction through fostering networks and building support. The system's location within its adaptive cycle will influence which of these strategies will be most effective at the given point in time (Fig. 2b).

Holling and Gunderson (2002) note that not all systems follow the same type of adaptive cycle. Indeed, some cycles are considered maladaptive and can cause a system's decline and eventual collapse. Poverty traps (Fig. 2a) are such an example: The erosion of potential and diversity in a system, through internal stress or an external disturbance, can cause a system's collapse, resulting in an impoverished state with low connectedness, low potential, and low resilience. Maladaptive systems can also be sustainable, in cases in which a system has developed high potential, high connectedness, and high resilience; this is known as a rigidity trap. A rigidity trap (Fig. 2a) represents a wealthy, tightly regulated, and resilient subsystem; however, this type of resilience is limited to the subsystem scale and emphasizes efficiency, control, constancy, and predictability, i.e., engineering resilience. When disturbance eventually occurs, there is little capacity to adapt, and the subsystem risks collapse with no renewal, potentially causing the overall system's decline.

In contrast, ecological resilience refers to persistence, adaptability, variability, and unpredictability as the measure of a healthy system's capacity to absorb disturbance and still maintain integrity of function and structure (Holling and Gunderson 2002). Further, functional integrity and structural integrity are not synonymous, and a system may actually require transformation of its structure to maintain resilience of its function (Smith and Stirling 2010). In other words, the shift of one scale into a new dynamic equilibrium is not necessarily bad for the system and may, in fact, be positive.
For urban water systems, regime structures that have evolved to facilitate centralized engineering solutions may need to transform for a city to maintain all its water-related functions, ranging from water supply to ecosystem services to urban amenity, as the traditional approach is challenged by contextual changes. In this sense, the goal of transformative change is to maintain ecological resilience of the overall system, rather than engineering resilience at the regime scale. The regime's adaptive capacity will therefore significantly influence which transition pathways are likely.

To integrate these resilience ideas into the proposed diagnostic procedure, constellations are considered to be conceptually positioned along an adaptive cycle, which represents their internal dynamics (Fig. 2c). The regime, composed of one or more constellations, follows a single adaptive cycle, and niche constellations each follow their own adaptive cycle. The progress of an adaptive cycle through periods of exploitation, conservation, release, and reorganization, or its lock-in to a poverty or rigidity trap, will depend on the development of internal constellation structures, external drivers, and dynamics between constellations at different scales.

The panarchy logic holds that these cross-scale dynamics between nested adaptive cycles, which we have interpreted as between a regime and niches, can lead to transformative change (Holling and Gunderson 2002). Geels and Schot (2007) argue that the type of transition path that unfolds because of regime-niche interactions will depend on the state of development of a niche at the time the regime comes under pressure. In this line of thinking, we propose that the presence of conditions for transformative change will largely depend on the relative positions of regime and niche constellations along their adaptive cycle at a given point in time.

The integration of transition theory's MPA and resilience theory's adaptive cycle provides a systemic framework for analyzing the dynamics of transformative change in an integrated system. However, the conceptual link with how human action can influence these dynamics is still missing. This leads to the introduction of concepts from institutional theory as the third building block of the proposed diagnostic procedure. As explained previously, the procedure adopts institutional change as the entry point for actors to enable system change because the biophysical functioning of urban socio-technical systems is fundamentally driven by human choices (Ferguson et al. 2013). Analysis of a system's institutions and processes of institutional change is therefore essential for understanding how actors can influence the system's dynamics.

Scott (2008) argues that institutions comprise all three institutional pillars, i.e., regulative, normative, and cultural cognitive. Institutions may be supported by one key pillar at a particular time, and as circumstances change, a different pillar may become dominant. However, in general, these rules, 
norms, and meanings need to work in combination to maintain resilient social structures. When the regulative, normative, and cultural-cognitive elements are not well aligned, there is likely to be confusion and conflict within an institution, creating conditions that are conducive to institutional change. This situation provides opportunity for actors to enable transformative change by mobilizing resources to exploit these differences. However, shifts in each of the pillars would need to be mutually reinforcing for a new set of institutions to eventually be stabilized. Therefore, purposeful strategic action for enabling a system transformation would need to target each of these three institutional elements in mutually reinforcing ways.

According to Scott (2008), cultural-cognitive institutions are the most deeply embedded in society and therefore the most difficult to change, whereas regulative institutions are the shallowest and therefore the easiest to change. In this sense, Roland (2004) classifies institutions as either "slow moving" or "fast moving." De la Torre-Castro and Lindström (2010) provide empirical evidence in a case study of fisheries management to demonstrate the slow-moving nature of cultural-cognitive and normative institutions, compared with fast-moving regulative institutions. The study concludes that "unless [regulative institutions such as property rights] rests [sic] on both the normative and the cultural-cognitive pillars, they are prone to fail" (de la Torre-Castro and Lindström 2010:82). From insights such as these, it appears that, although shifts in the three institutional pillars should be mutually reinforcing, at the system-wide scale there is likely to be a dominant and sequential pattern in how transformative institutional change occurs. As such, we hypothesize that a deep cultural-cognitive shift is most likely to initially drive a transition, followed by corresponding normative and regulative shifts. In turn, the development of regulative structures is likely to be the principle focus toward the end of the transition, as formal rules, laws, and sanctions incrementally work to stabilize the new transformed system.

Mapping this sequence of institutional change, i.e., cultural cognitive, then normative, and then regulative, onto the adaptive cycle provides a conceptual base for guiding which institutional pillars should be the focus of strategic initiatives during different phases of change for individual constellations (Fig. 2d). For example, cultural-cognitive mechanisms are expected to be most effective during the $\Omega$, i.e., release, and $\alpha$, i.e., reorganization, phases of the adaptive cycle, when the previous system conditions have destabilized, uncertainty dominates, and changed meanings can lead to system renewal. Normative mechanisms are expected to be most effective during the $\alpha$ and $r$, i.e., exploitation, phases of the adaptive cycle, when the period of experimentation results in multiple innovations that compete for resources, only some of which will survive and be exploited. Regulative mechanisms are expected to be most effective during the $r$ and $K$ phases, when "winners" accumulate resources and become increasingly connected. Although these hypotheses hold logical validity, they require substantiation. Nonetheless, they lead to the conclusion that the choice of strategic initiatives should account for the sequential logic of how institutional pillars shift to reinforce each other. Note that this conceptual framing is not intended to provide predictive capacity in a temporal sense, but rather to indicate the likely sequencing of change.

The final concept introduced to the proposed diagnostic procedure, institutional work, links different types of action by individuals and organizations with the institutional pillars targeted for strategic intervention. Lawrence and Suddaby (2006) reviewed empirical-based research on institutions to draw insights into the distinct sets of practices that actors employed to create, maintain, and disrupt institutions. Table 2 lists these sets of empirically observed mechanisms and categorizes them according to whether they most closely act on the regulative, normative, or cultural-cognitive institutional pillar. Explanation of each form of institutional work is provided, with brief examples of activities that actors may undertake in doing the institutional work. Although Lawrence and Suddaby (2006) acknowledge that their typology of mechanisms could be expanded, it is useful as a means to identify distinct categories of institutional work that can be seen to act on each of the institutional pillars.

Mechanisms of institutional work are how actors can influence the institutional dynamics of a societal system. In the case of an urban water system, changes to its biophysical structures, e.g., rivers and pipelines, will be facilitated by actors initiating changes to its social structures, e.g., policies and design standards, through the employment of different forms of institutional work. Therefore, analysts can identify strategic action types based on an assessment of what institutions need to be created, maintained, and/or disrupted and how to most effectively influence the institutions at a particular point in time, whether via the regulative, normative, or culturalcognitive elements, given the adaptive cycle position (Fig. 3).

\section{Proposed diagnostic procedure}

Integration of the MPA, adaptive cycle, institutional pillars, and institutional work mechanisms provides the conceptual basis for identifying which types of strategic action would be most effective for enabling change in a complex system characterized by uncertainty and nonlinear change. For example, at a given point in time strategic planners need to understand the current state of the system, the phase of change for individual constellations, and the type of upcoming changes that are expected so that interventions can focus on which mechanisms are likely to be most effective in the short and long term. The proposed diagnostic procedure follows the five steps described subsequently (see also Figs. 4 and 5). 
Table 2. Explanations of mechanisms of institutional work for each institutional pillar (see Lawrence and Suddaby 2006, for more details).

\begin{tabular}{|c|c|c|c|c|c|c|}
\hline \multirow{2}{*}{$\frac{\text { PILLAR }}{\text { Regulative }}$} & \multicolumn{2}{|r|}{ Creating Institutions } & \multicolumn{2}{|r|}{ Maintaining Institutions } & \multicolumn{2}{|c|}{ Disrupting Institutions } \\
\hline & Defining & $\begin{array}{l}\text { Defining rules and boundaries through } \\
\text { activities that, for example, allocate } \\
\text { responsibilities, create membership rules, } \\
\text { formalize standards and compliance criteria, } \\
\text { introduce accreditation and certification } \\
\text { schemes. }\end{array}$ & $\begin{array}{l}\text { Enabling } \\
\text { work }\end{array}$ & $\begin{array}{l}\text { Creating rules through activities } \\
\text { such as amending regulations and } \\
\text { setting targets, to enable } \\
\text { authorizing agents to carry out } \\
\text { routines, divert resources and } \\
\text { create certainty for institutional } \\
\text { survival. }\end{array}$ & $\begin{array}{l}\text { Disconnecting } \\
\text { sanctions / } \\
\text { rewards }\end{array}$ & $\begin{array}{l}\text { Disconnecting } \\
\text { rewards and sanctions } \\
\text { from institutionalized } \\
\text { practices, } \\
\text { technologies or rules, } \\
\text { for example, through } \\
\text { court rulings, } \\
\text { challenges to the } \\
\text { prevailing regulatory } \\
\text { structure, and } \\
\text { redefinition of } \\
\text { technical standards } \\
\text { and assumptions on } \\
\text { which an institution is } \\
\text { based. }\end{array}$ \\
\hline & Vesting & $\begin{array}{l}\text { Dividing vested rights and interests by } \\
\text { government authorities through processes such } \\
\text { as regulative bargaining to create new actors } \\
\text { and change market rules and relations. }\end{array}$ & Policing & $\begin{array}{l}\text { Using sanctions and rewards to } \\
\text { enforce, audit and monitor } \\
\text { compliance of institutionalized } \\
\text { practices. }\end{array}$ & & \\
\hline & Advocacy & $\begin{array}{l}\text { Influencing the allocation of resources and } \\
\text { socio-political support through activities such } \\
\text { as lobbying, advertising, promoting agendas } \\
\text { and litigation. }\end{array}$ & Deterring & $\begin{array}{l}\text { Using economic or authoritative } \\
\text { measures to provide the threat of } \\
\text { coercion and instill conscious } \\
\text { obedience of actors. }\end{array}$ & & \\
\hline \multirow[t]{3}{*}{ Normative } & $\begin{array}{l}\text { Constructing } \\
\text { identities }\end{array}$ & $\begin{array}{l}\text { Collective action to create shared } \\
\text { understandings of the relationship between } \\
\text { actors and their field of work, particularly in } \\
\text { the emergence of new or transformation of } \\
\text { existing professions. }\end{array}$ & $\begin{array}{l}\text { Valourizing } \\
\text { and } \\
\text { demonizing }\end{array}$ & $\begin{array}{l}\text { Promoting particularly positive or } \\
\text { negative examples that illustrate } \\
\text { the moral foundations of the } \\
\text { institution, for example, public } \\
\text { recognition of 'good' and 'bad' } \\
\text { practices. }\end{array}$ & $\begin{array}{l}\text { Disassociating } \\
\text { moral } \\
\text { foundations }\end{array}$ & $\begin{array}{l}\text { Gradually } \\
\text { undermining the } \\
\text { moral foundations of } \\
\text { institutions through } \\
\text { indirect sets of } \\
\text { practices. }\end{array}$ \\
\hline & $\begin{array}{l}\text { Changing } \\
\text { normative } \\
\text { associations }\end{array}$ & $\begin{array}{l}\text { Extending or adapting existing practices to } \\
\text { promote new moral and cultural associations } \\
\text { through activities that create strategic } \\
\text { realignments and develop new policy } \\
\text { directions. }\end{array}$ & & & & \\
\hline & $\begin{array}{l}\text { Constructing } \\
\text { normative } \\
\text { networks }\end{array}$ & $\begin{array}{l}\text { Creating loose peer networks that normatively } \\
\text { sanction certain practices and exist in parallel } \\
\text { to established institutional structures, through } \\
\text { activities that bring people together, for } \\
\text { example, workshops, conferences, } \\
\text { demonstration projects or case studies. }\end{array}$ & Mythologizing & $\begin{array}{l}\text { Creating and sustaining myths } \\
\text { around the history of the } \\
\text { institution through story-telling in } \\
\text { a public arena. }\end{array}$ & & \\
\hline \multirow[t]{3}{*}{$\begin{array}{l}\text { Cultural- } \\
\text { Cognitive }\end{array}$} & Mimicry & $\begin{array}{l}\text { Leveraging existing taken-for-granted } \\
\text { practices, technologies and rules to associate } \\
\text { new with old to ease adoption, for example, } \\
\text { designing elements and selecting symbols to } \\
\text { mimic and emphasize similarities with the old. }\end{array}$ & $\begin{array}{l}\text { Embedding } \\
\text { and } \\
\text { routinizing }\end{array}$ & $\begin{array}{l}\text { Embedding daily routines and } \\
\text { repetitive practices with } \\
\text { institutional values and morals } \\
\text { through activities such as training, } \\
\text { education, recruitment, } \\
\text { certification and ceremony. }\end{array}$ & $\begin{array}{l}\text { Undermining } \\
\text { assumptions } \\
\text { and beliefs }\end{array}$ & $\begin{array}{l}\text { Decreasing the costs } \\
\text { associated with a new } \\
\text { practice, technology } \\
\text { or rule through } \\
\text { innovation that breaks } \\
\text { existing institutional } \\
\text { assumptions and } \\
\text { templates, or gradual } \\
\text { undermining through } \\
\text { contrary practice. }\end{array}$ \\
\hline & Theorizing & $\begin{array}{l}\text { Naming and developing a language around } \\
\text { new concepts and practices to cognitively map } \\
\text { them within the field, and articulating } \\
\text { narratives of cause-and-effect relationships } \\
\text { among institutional elements. }\end{array}$ & & & & \\
\hline & Educating & $\begin{array}{l}\text { Developing new skills and knowledge in } \\
\text { actors to support novel practices through } \\
\text { activities such as training programs, } \\
\text { establishment of working groups, } \\
\text { demonstration projects, case studies, creation } \\
\text { of guidelines, frameworks and templates. }\end{array}$ & & & & \\
\hline
\end{tabular}


Fig. 3. Institutional work mechanisms that (a) create, (b) maintain, and (c) disrupt institutions (Lawrence and Suddaby 2006). These are conceptually positioned at different phases of the adaptive cycle to align with the institutional pillar (Scott 2008) that we hypothesize would represent the most effective mechanisms for the system conditions at that particular adaptive cycle position. (Note that the sequential order of individual mechanisms within the adaptive cycle phase for each pillar is not important, only the overall category of mechanisms that are indicated by the institutional pillar.)

\section{(a) Create institutions}

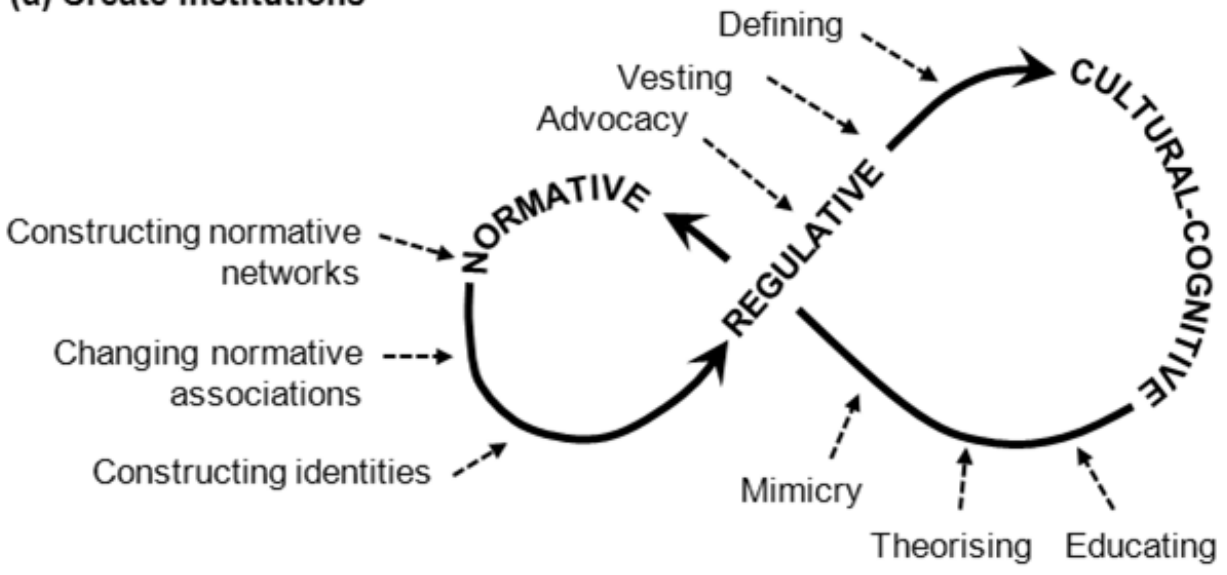

(b) Maintain institutions

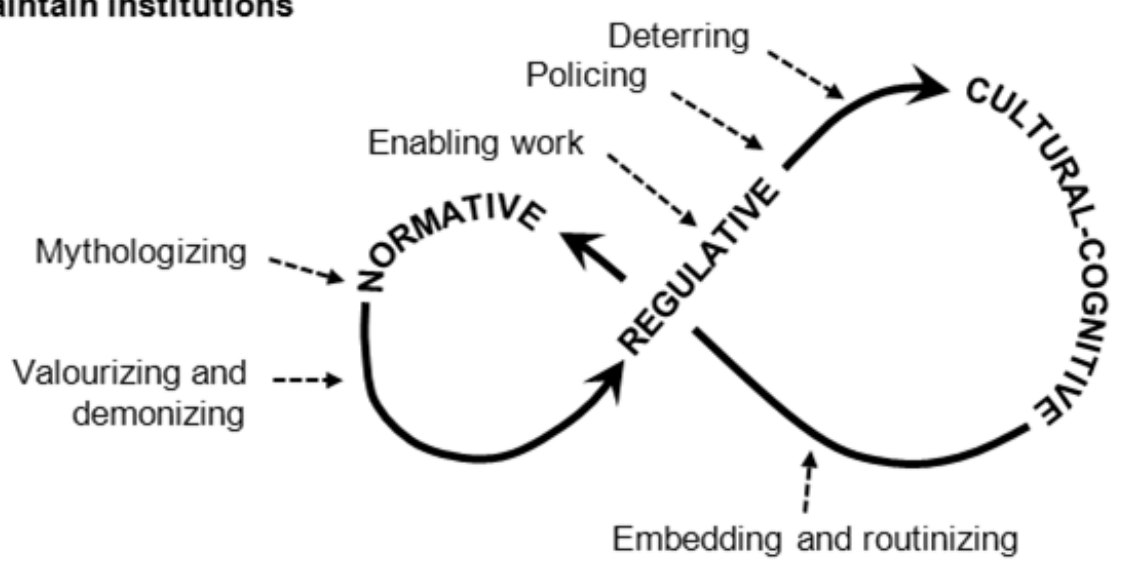

(c) Disrupt institutions

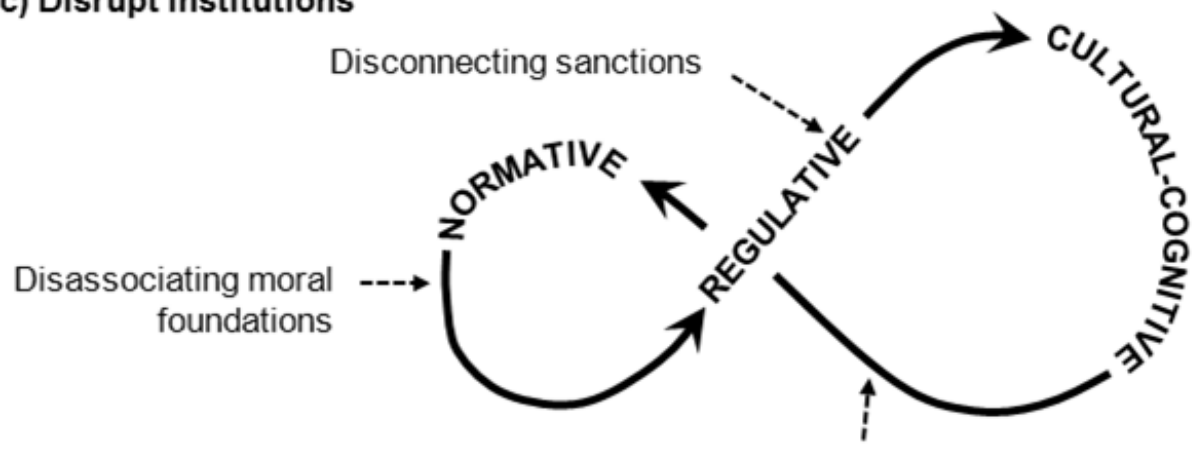

Undermining assumptions and beliefs 
Fig. 4. Steps 1, 2, and 3 of the proposed diagnostic procedure.

STEP 1. CURRENT AND DESIRED FUTURE SYSTEM COMPOSITIONS
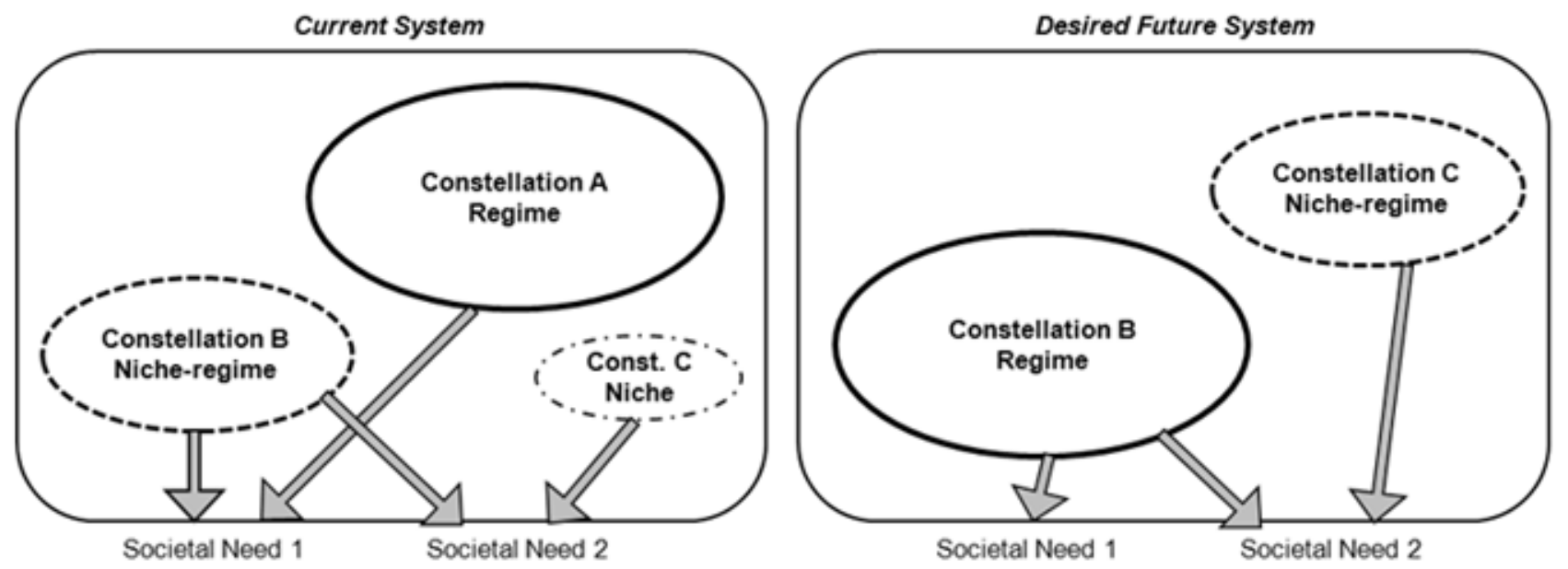

STEP 2. PATTERNS AND CONDITIONS OF TRANSITIONAL CHANGE

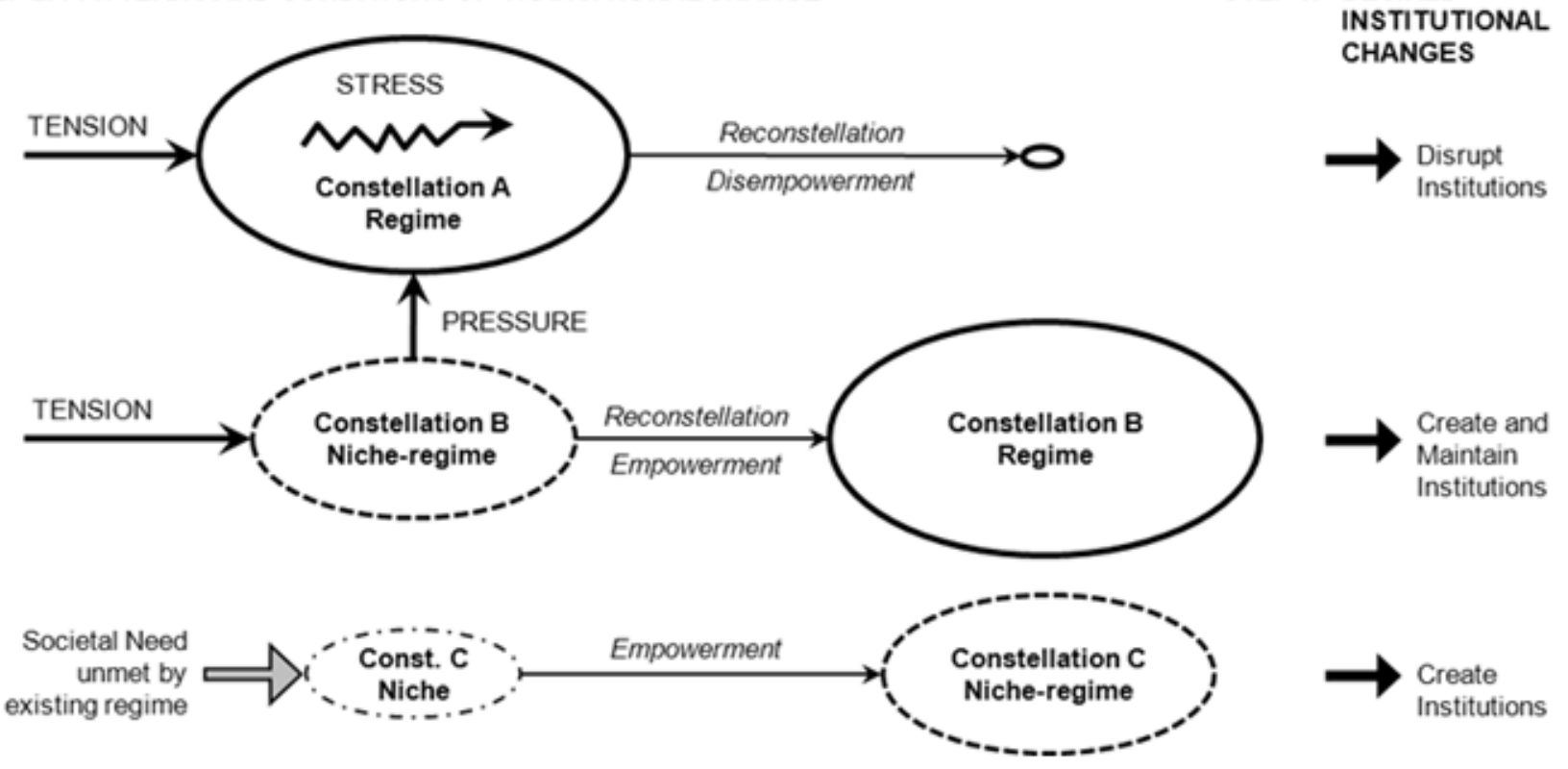

Step 1. Define current system composition and envision desired future system composition (Fig. 4).

Identify the constellations that currently comprise the system and empirically map how each meets different components of society's needs. Follow envisioning processes to map the desired future system and define its composition. There is extensive scholarship on processes for futures studies, for example, visioning, backcasting, road mapping, and scenario planning (e.g., Ziegler 1991, Swart et al. 2004, Börjeson et al. 2006, Dreborg 2006, Robinson et al. 2011). Details of these processes are beyond the scope of this discussion, but we highlight that a suitable and rigorous methodology should be selected and that broad participatory approaches are typically preferred.

Step 2. Determine the possible transition conditions for driving desired transition patterns (Fig. 4).

Determine which transition patterns, i.e., reconstellation, empowerment, or adaptation, would be likely to result in the system composition changes required for the desired transformation. Then determine the conditions for transformative change, i.e., tension, pressure, or stress, that would be likely to drive these patterns. 
Fig. 5. Steps 4 and 5 of the proposed diagnostic procedure.

\section{STEP 4. CURRENT PHASE OF CHANGE}

Constellation A: Regime

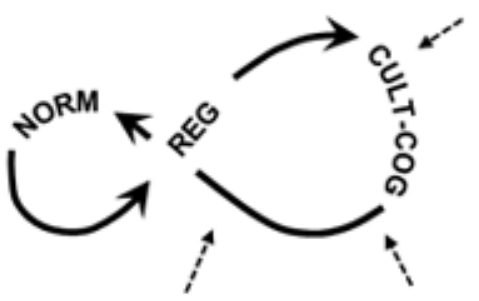

Cultural-cognitive

Current adaptive cycle location

Next likely adaptive cycle location

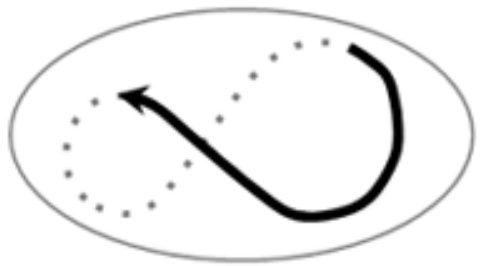

Cultural-cognitive

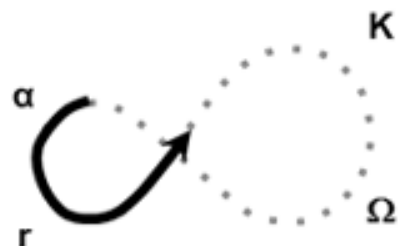

Normative

Regulative
Constellation B: Niche-Regime

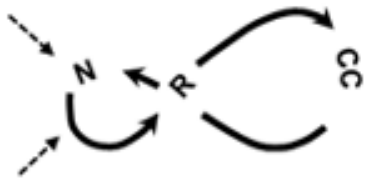

Normative

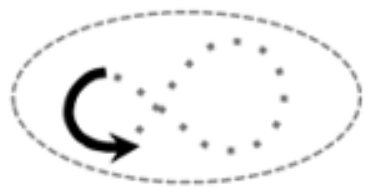

Normative

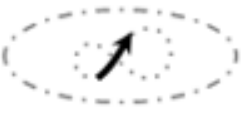

Regulative

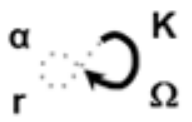

Cultural-cognitive

STEP 5. FUTURE INSTITUTIONAL WORK MECHANISMS

\begin{tabular}{|r|r|r|c|}
\hline \multicolumn{1}{|l|}{$\begin{array}{l}\text { Select and design strategic action initiatives } \\
\text { (refer Table 2) }\end{array}$} & \multicolumn{3}{|c|}{$\begin{array}{c}\text { Institutional Work Mechanisms } \\
\text { (Step 3) }\end{array}$} \\
\hline Institutional Pillar (Step 4) & Create Institutions & Maintain Institutions & Disrupt Institutions \\
\hline Regulative & \multicolumn{2}{|c|}{ Constellation B } & \multirow{2}{*}{ Constellation A } \\
\hline Normative & & & \\
\hline Cultural-Cognitive & Constellation C & & \\
\hline
\end{tabular}

Step 3. Determine the institutional changes that could induce the conditions for change (Fig. 4).

Determine which type of institutional change processes, i.e., create, maintain, or disrupt, for each constellation could induce the conditions for the desired transformative change identified in step 2. Note that the "tension" condition would not be induced through institutional change because, by definition, tension occurs when a landscape force acts on the system. The aim is therefore to create, maintain, or disrupt institutions within constellations so that when a landscape influence does result in the tension condition being present, the constellations exert complementary stress or pressure conditions to drive a transition pattern.

Step 4. Determine the phase of change for each constellation (Fig. 5).

Determine each constellation's current phase of change, i.e., adaptive cycle, by mapping its recent history of change using 
empirical data. The effectiveness of different mechanisms of institutional work provides an indicator of where in the adaptive cycle the constellation is currently positioned. For example, if the focus of recent strategic initiatives had been on regulative dimensions, the constellation is likely to be in the $r$ to $K$ phase. If the focus had recently been on network building and experimentation, the constellation is likely to be in the $\alpha$ to $r$ phase. Tracing the history of change back to one previous adaptive cycle location should be sufficient to identify the current location. Once the current phase of change has been mapped, identify the phase of change that is likely to occur next by examining the adaptive cycle position. This then implies which institutional pillar, i.e., cultural cognitive, normative, or regulative, should be focused on through strategic initiatives for institutional work mechanisms to be most effective.

\section{Step 5. Identify institutional work mechanisms that best fit} the current system conditions (Fig. 5).

Use the outcomes of steps 3 and 4 to identify the category of institutional work mechanisms that should be employed through strategic initiatives to most effectively enable a transition. Select mechanisms according to whether the aim is to create, maintain, or disrupt institutions and whether the phase of change is in the cultural-cognitive, normative, or regulative part of the adaptive cycle. Short-term strategic initiatives and long-term planning activities can then be identified for implementing these mechanisms.

Drawing on the strategies identified by Olsson et al. (2006), actors can prepare for system transformation by anticipating when windows of opportunities are likely to occur and undertaking institutional work activities that ensure the niche constellations are in the $r$ or $K$ phase of the adaptive cycle, for example, through activities that build up knowledge, leadership capacity, and shadow networks. In these phases, niches are best prepared to influence the regime when a strong landscape influence opens a window of opportunity. Similarly, actors can undertake institutional work that encourages regimes to be in the $\Omega$ or $\alpha$ phase of the adaptive cycle, e.g., through activities that challenge existing assumptions and knowledge, to maximize their capacity to adapt, as well as to escape rigidity and poverty traps. Once a window of opportunity has opened, there is the potential for navigating a transition and fostering resilience of the new system by undertaking institutional work that encourages new innovations and breaks down any barriers that would prevent stabilization of the new system composition.

\section{EXAMPLE APPLICATION OF THE DIAGNOSTIC PROCEDURE}

Figures 6 and 7 provide a simplified application of the diagnostic procedure to a case study from Melbourne, Australia. The case study was a grounded historical analysis of the transformation in urban storm water management between 1960 and 2006 (refer to Brown et al. 2013, for full details). The study provides an example of how actors in an international leading city from a waterways management perspective (Roy et al. 2008, Jefferies and Duffy 2011) were able to transform the mainstream approach of piped drainage to incorporate water sensitive urban design (WSUD) practices.

For the case study period, the system functioning was dominated by a piped drainage regime that aimed to rapidly convey large volumes of storm water to receiving water bodies. Downstream waterways were highly polluted because storm water quality was not a consideration of this piped drainage regime. However, from the 1960s, there was growing community awareness and concern about the poor health of Melbourne's waterways. These concerns continued throughout the case study period and are conceptualized as landscape influences of environmentalism and waterway pollution. In response to these tensions and the unmet societal need for ecosystem protection, a WSUD niche emerged during the 1990s. The innovative approaches in the WSUD constellation aimed to improve the quality of storm water before it entered the receiving waterways, thereby reducing the level of pollution in downstream waters. With the support of research and development, demonstration projects, and growing practitioner networks, the WSUD niche gradually increased its power over the years. By 2006, the WSUD niche had stabilized into a niche-regime that was sufficiently powerful to compete with the established piped drainage regime in providing system function to meet society's need for ecosystem protection and drainage. Figures 6 and 7 apply the proposed diagnostic procedure to demonstrate how it can be used to explain and anticipate the transformative dynamics in Melbourne's storm water management and therefore lead to insights for identifying which types of future strategic initiatives would best fit the system conditions in 2006 .

Step 1 used empirical data to map the 2006 system, identifying that both the piped drainage regime and the WSUD niche regime met the societal need for drainage. However, only the WSUD niche regime met the need for ecosystem protection. The envisioned future system, approximately 10 years later, in 2016, comprises a regime that incorporates both piped drainage and WSUD structures, such that ecosystem protection and drainage needs are well met by structures that address both storm water quantity and quality.

Step 2 determined that for this combined regime to be achieved, the current piped drainage regime would need to adapt to incorporate the WSUD structures. Transition patterns of reconstellation and/or adaptation could lead to this change. At the same time, the WSUD niche regime would need to continue to grow in power so that it increases its influence on the regime and offers a viable means for the regime to meet the need for ecosystem protection, i.e., the empowerment 
Fig. 6. Application of Steps 1, 2, and 3 of the proposed diagnostic procedure to the Melbourne case study for 2006: Piped Drainage Regime and WSUD Niche-Regime.

STEP 1. CURRENT AND DESIRED FUTURE SYSTEM COMPOSITIONS
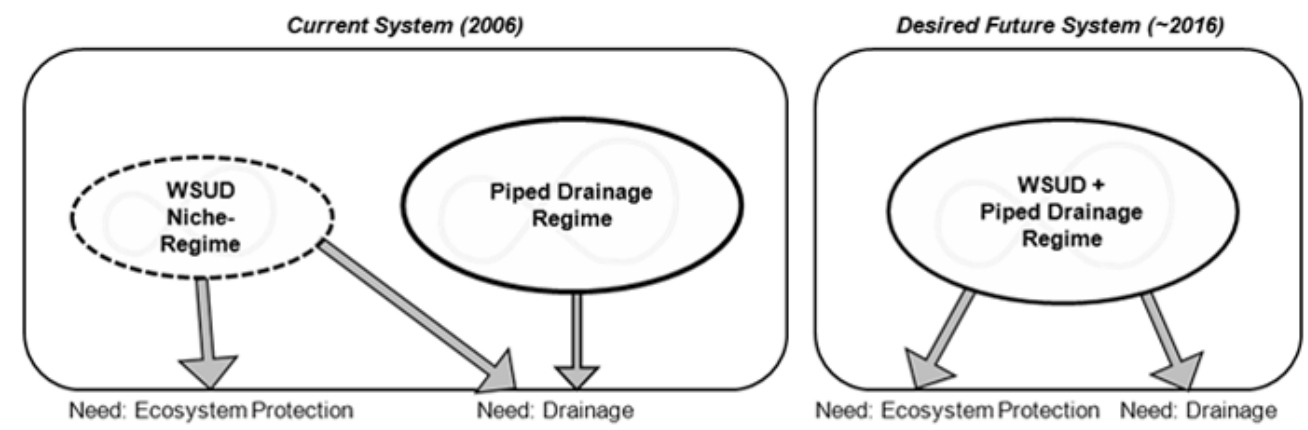

STEP 2. PATTERNS AND CONDITIONS OF TRANSITIONAL CHANGE

Transition Patterns for Achieving Desired Future

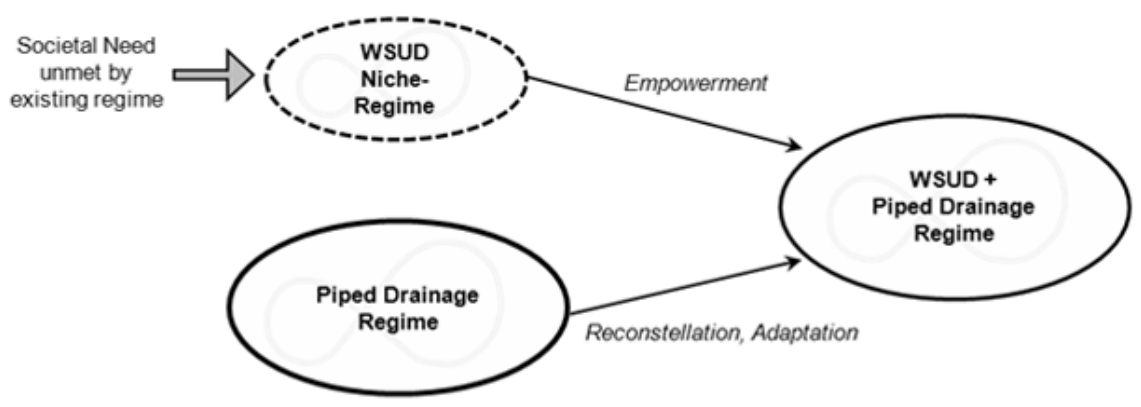

Transition Conditions to Drive Required Patterns

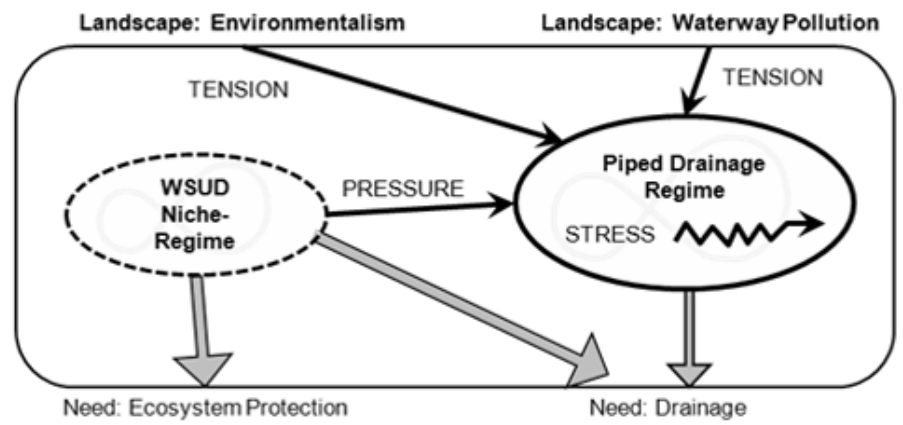

STEP 3. DESIRED INSTITUTIONAL CHANGES

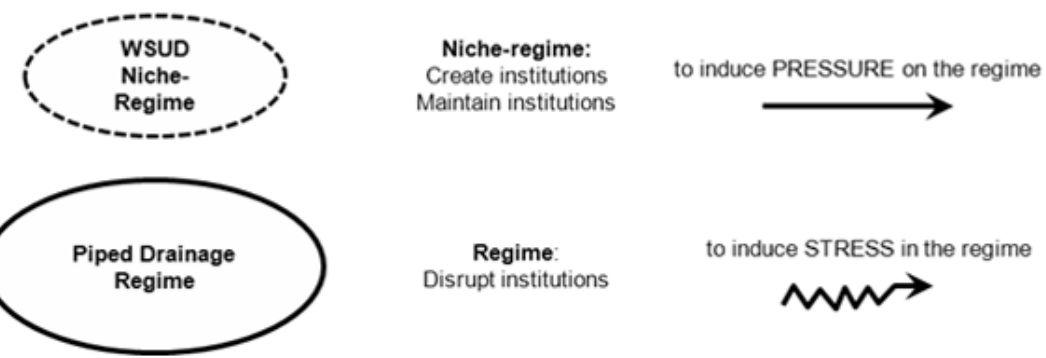


Fig. 7. Application of Steps 4 and 5 of the proposed diagnostic procedure to the Melbourne case study for 2006: Piped Drainage Regime and WSUD Niche-Regime.

\section{STEP 4. CURRENT PHASE OF CHANGE}

Institutional Work Mechanisms for 2000 - 2006

Adaptive Cycle Location for 2006 - 2016

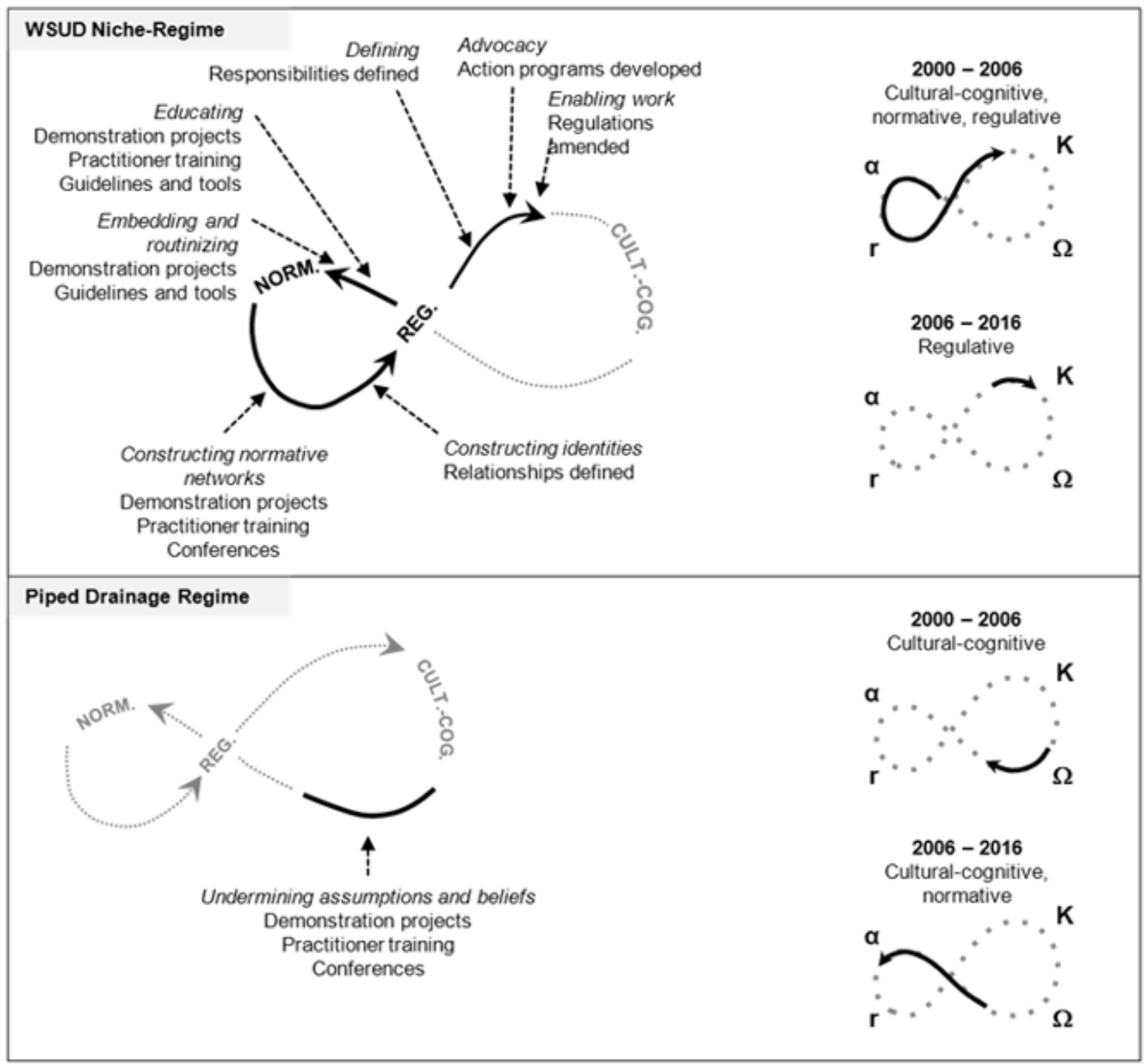

STEP 5. FUTURE INSTITUTIONAL WORK MECHANISMS

\begin{tabular}{|r|r|r|c|}
\hline \multicolumn{1}{|l|}{$\begin{array}{l}\text { Select and Design } \\
\text { Strategic Action Initiatives }\end{array}$} & \multicolumn{3}{|c|}{ Institutional Work Mechanisms } \\
\hline Institutional Pillar & Create Institutions & Maintain Institutions & Disrupt Institutions \\
\hline Regulative & \multicolumn{2}{|c|}{ WSUD Niche-Regime } & \\
\hline Normative & & & \multirow{2}{*}{$\begin{array}{c}\text { Piped Drainage } \\
\text { Regime }\end{array}$} \\
\hline Cultural-Cognitive & & & \\
\hline
\end{tabular}


transition pattern. The transition conditions on the piped drainage regime that could lead to reconstellation and/or adaptation are a combination of external tension, internal stress attributable to an inability to meet societal needs, and pressure from the competing WSUD niche regime. In 2006, tension was already present in the form of environmentalism and waterway pollution.

Step 3 identified that pressure on the regime could be induced if the WSUD niche regime maintains its existing institutions and creates new institutions. Further, stress in the regime could be induced if, through mechanisms that disrupted institutions, the piped drainage regime recognized its inability to meet the societal need for ecosystem protection.

Step 4 mapped the system changes that occurred between 2000 and 2006 to identify the adaptive cycle positions of both constellations. The institutional work mechanisms between 2000 and 2006 that led to niche growth, such that it became a WSUD niche regime, included demonstration projects, sharing of knowledge through practitioner training and conferences, formalization of relationships, implementation of action plans, development of guidelines and other tools, and amendment of regulations. These mechanisms were cultural cognitive, normative, and regulative in nature. This information alone is insufficient to determine the precise adaptive cycle position, given that the mechanisms were aligned with all three institutional pillars. However, analysis of empirical data from 1960 to 2000 traced the institutional work mechanisms back to previous adaptive cycle positions and determined the 2006 location shown in Figure 7; we have not presented the analysis between 1960 and 2000 because of space limitations. Given its phase of change in 2006, the WSUD niche regime is likely to remain in the $K$ phase of the adaptive cycle, where regulative institutional work is expected to be most effective for the next phase. From 2006 onward, the regime is likely to move through the "back loop" of the adaptive cycle between the $\Omega$ and $\alpha$ phases, where culturalcognitive and normative institutional work mechanisms are likely to be most effective.

Step 5 drew on the outcomes of steps 3 and 4 to identify which type of institutional work mechanisms are expected to best fit the 2006 conditions, to achieve a future system in which a regime combines both piped drainage and WSUD structures. Use of the diagnostic procedure indicates that institutional work mechanisms for the 2006 WSUD niche regime should aim to create and maintain institutions that are regulative in nature. Mechanisms for the 2006 piped drainage regime should aim to disrupt institutions that are cultural cognitive and normative in nature. Actors should therefore consider how the relevant institutional work mechanisms (Table 2) are best employed through the selection of particular strategic initiatives.

\section{DISCUSSION AND CONCLUSIONS}

Concepts in transition theory and resilience theory offer a promising basis for analyzing the dynamic patterns of transformative change. Although there are some differences in the background and approach of these two fields, they have fundamentally similar understandings of dynamic transformative change. The MPA, from transition theory, identifies the system conditions and changes that are considered necessary for enabling a system transformation. The adaptive cycle, from resilience theory, identifies the current phase of change for different parts of the system. Institutional theory provides a valuable understanding of the links between human action and its impact on transformative change. Used in conjunction with insights into the transformative dynamics of a system, the concepts of institutional pillars and institutional work identify which type of mechanisms are likely to be most effectively employed through strategic initiatives to enable a transition toward a desired future. We have integrated concepts from these three theoretical fields to propose a diagnostic procedure for revealing insights into which types of strategic action are most likely to influence the direction and pace of change in an overall system toward a desired trajectory. To provide some reflection on the potential for this procedure to support strategic planning for transformative change in urban water systems, we consider the scope for an operational diagnostic procedure proposed by Ferguson et al. (2013).

The procedure should address a set of nested DQs that provide retrospective analysis of a system problem or changes. It should offer analytic lenses that relate to the broad system scale, individual variables, static snapshots in time, and dynamic links between system states.

Ferguson et al. (2013) propose a general set of DQs for transformative change in urban water systems. Given the system-wide focus of the procedural steps we have presented, they address the questions relevant for the whole system, considering both static snapshots and their dynamic links (Table 3). The DQs related to individual variables and relationships (DQs 3, 4, and 5) are not addressed by the proposed procedure. Additional steps, underpinned by different analytic frameworks, would need to be incorporated if the procedure were to consider individual variables.

The procedure should be capable of analyzing system variables that are actors, structures, processes, contexts, and outcomes.

The system-wide focus of the proposed diagnostic procedure gives it a functionalistic perspective. Actors and structures are considered only in terms of their function in the system. Contextual factors are conceptualized as landscape influences on the system functioning. Outcomes are expressed as the degree to which societal needs are met by the system functioning. Processes are considered in terms of the institutional work mechanisms that function to create, maintain, or disrupt institutions. If a different perspective, for 
Table 3. Diagnostic questions addressed by the proposed diagnostic procedure.

\begin{tabular}{|c|c|}
\hline $\begin{array}{l}\text { Step in Proposed } \\
\text { Diagnostic Procedure }\end{array}$ & $\begin{array}{l}\text { Diagnostic Question Addressed } \\
\text { (Ferguson et al. 2013) }\end{array}$ \\
\hline Define current system composition and envision desired future composition & DQ 1. Take system snapshots in time \\
\hline $\begin{array}{l}\text { 2. Determine the possible transition conditions for driving desired transition } \\
\text { patterns }\end{array}$ & DQ 6. Predict impacts of system changes \\
\hline Determine the institutional changes that could induce the conditions for change & DQ 6. Predict impacts of system changes \\
\hline Determine the phase of change for each constellation & DQ 2. Trace system changes over time \\
\hline $\begin{array}{l}\text { 5. Identify institutional work mechanisms that best fit the current system } \\
\text { conditions }\end{array}$ & DQ 7. Predict suite of strategic action initiatives \\
\hline \multicolumn{2}{|l|}{$\begin{array}{l}\text { The following diagnostic questions are not addressed by the proposed diagnostic procedure: } \\
\text { DQ 3. Identify causal variables } \\
\text { DQ 4. Identify causal relationships } \\
\text { DQ 5. Trace impacts of causal variables and relationships }\end{array}$} \\
\hline
\end{tabular}

example, actor networks and power relationships, is required for a particular application, additional steps that are underpinned by different analytic frameworks would need to be incorporated into the procedure.

The procedure should incorporate a methodological framework that provides operational guidance.

The diagnostic procedure provides clear methodological steps for consistent empirical application to gain generalized insights.

The procedure should be underpinned by conceptual frameworks that provide a description and an explanation of a system problem or changes.

The diagnostic procedure is underpinned by concepts, i.e., the MPA and the adaptive cycle, that are capable of both describing and explaining a system's transformative dynamics observed in empirical data.

The procedure should be capable of providing predictions about the impacts of strategic action on a system's dynamics. It should be capable of informing the selection of strategic initiatives that best fit the current system conditions.

Our hypothesis regarding the sequential nature of effective institutional work mechanisms, in relation to the adaptive cycle and institutional pillars, needs further substantiation. The hypothesized correlation between the presence of conditions for transformative change and the relative positions of constellations along their adaptive cycles also needs substantiation. In particular, case studies of successful and unsuccessful transformative change that demonstrate the effectiveness of different types of strategic initiatives should be investigated and analyzed through the diagnostic procedure to validate its ability to describe, explain, and predict the different types of change observed in the cases. With this further substantiation, the diagnostic procedure would be capable of anticipating how different mechanisms could impact on the system, thereby enabling an analyst to follow a process of deduction to identify which types of strategic action best fit the current system conditions.

We hope this exploration of how concepts from different theories can be integrated into a diagnostic procedure makes a contribution to the current scholarly activity focused on diagnostic approaches for addressing the science and policy questions concerning how transitions can be navigated to support the shift toward sustainability in urban water servicing and other infrastructure sectors. We suggest that, with further empirical testing and subsequent refinements of the diagnostic procedure, the integration of the transitions, resilience, and institutional concepts that we have proposed would be a useful platform from which to develop an operational tool that planners, policy analysts, and decision makers could use to diagnose critical mechanisms of transformative change and therefore identify which types of strategic action are likely to provide the best fit, given the current system conditions.

Use of diagnostic approaches to support the planning of infrastructure systems would address some of the critical flaws in planning agendas that focus on controlling variables and reducing uncertainties for linear change processes. Instead, it would enable scholars and practitioners to examine proposed policy and action within the context of the broader system, embracing the reality of its complexity, interconnectedness, and contextual uncertainty that frames society's needs from its infrastructure. This perspective would be particularly valuable for cases in which transformative change of the system is considered necessary to achieve sustainable outcomes. It would provide insight into the likely timing of windows of opportunity so that strategic initiatives could be selected to achieve maximum effectiveness at different phases of a transformation and to prepare the system for likely upcoming changes. Finally, it would provide actors with a systemic understanding of how adaptive change can be 
welcomed rather than resisted, encouraging the proactive development of strategic plans to increase adaptive capacity and facilitate the transition toward a resilient and sustainable system.

Responses to this article can be read online at: http://www.ecologyandsociety.org/issues/responses. php/5901

\section{Acknowledgments:}

The authors would like to thank the anonymous reviewer for valuable feedback. This research was conducted as part of the EU 7th Framework Programme, "PREPARED: Enabling Change," and contributes to the development of an explorative computational planning tool, DAnCE4Water (Dynamic Adaptation for eNabling City Evolution for Water).

\section{LITERATURE CITED}

Battilana, J., and T. D'Aunno. 2009. Institutional work and the paradox of embedded agency. Pages 31-58 in T. B. Lawrence, R. Suddaby, and B. Leca, editors. Institutional work: actors and agency in institutional studies of organizations. Cambridge University Press, Cambridge, UK.

Berkes, F., J. Colding, and C. Folke, editors. 2003. Navigating social-ecological systems: building resilience for complexity and change. Cambridge University Press, Cambridge, UK.

Berkes, F., C. Folke, and J. Colding, editors. 1998. Linking social-ecological systems: management practices and social mechanisms for building resilience. Cambridge University Press, Cambridge, UK.

Berkhout, F. 2002. Technological regimes, path dependency and the environment. Global Environmental Change 12:1-4. http://dx.doi.org/10.1016/S0959-3780(01)00025-5

Berkhout, F., A. Smith, and A. Stirling. 2004. Socio-technical regimes and transition contexts. Pages 48-75 in B. Elzen, F. W. Geels, and L. Green, editors. System innovation and the transition to sustainability. Edward Elgar, Cheltenham, UK.

Börjeson, L., M. Höjer, K.-H. Dreborg, T. Ekvall, and G. Finnvedan. 2006. Scenario types and techniques: towards a user's guide. Futures 38(7):723-739. http://dx.doi.org/10.1016/ j.futures.2005.12.002

Brown, R. R., M. A. Farrelly, and D. A. Loorbach. 2013. Actors working the institutions in sustainability transitions: the case of Melbourne's stormwater management. Global Environmental Change 23:701-718. http://dx.doi.org/10.1016/ j.gloenvcha.2013.02.013
Chapin, F. S., III, S. R. Carpenter, G. P. Kofinas, C. Folke, N. Abel, W. C. Clark, P. Olsson, D. M. S. Smith, B. Walker, O. R. Young, F. Berkes, R. Biggs, J. M. Grove, R. L. Naylor, E. Pinkerton, W. Steffen, and F. J. Swanson. 2010. Ecosystem stewardship: sustainability strategies for a rapidly changing planet. Trends in Ecology \& Evolution 25(4):241-249. http:// dx.doi.org/10.1016/j.tree.2009.10.008

Chapin, F. S., III, G. P. Kofinas, and C. Folke, editors. 2009. Principles of ecosystem stewardship: resilience-based natural resource management in a changing world. Springer, New York, New York, USA.

Cox, M. 2011. Advancing the diagnostic analysis of environmental problems. International Journal of the Commons 5(2):346-363.

de Graaf, R., and R. van der Brugge. 2010. Transforming water infrastructure by linking water management and urban renewal in Rotterdam. Technological Forecasting and Social Change 77(8):1282-1291. http://dx.doi.org/10.1016/j. techfore.2010.03.011

de Haan, J. 2010. Towards transition theory. Dissertation, Erasmus University, Rotterdam, The Netherlands.

de Haan, J., and J. Rotmans. 2011. Patterns in transitions: understanding complex chains of change. Technological Forecasting and Social Change 78(1):90-102. http://dx.doi. org/10.1016/j.techfore.2010.10.008

de la Torre-Castro, M., and L. Lindström. 2010. Fishing institutions: addressing regulative, normative and culturalcognitive elements to enhance fisheries management. Marine Policy 34(1):77-84. http://dx.doi.org/10.1016/j.marpol.2009.04.012

Dolata, U. 2009. Technological innovations and sectoral change: transformative capacity, adaptability, patterns of change: an analytical framework. Research Policy 38 (6):1066-1076. http://dx.doi.org/10.1016/j.respol.2009.03.006

Dominguez, D., H. Worch, J. Markard, B. Truffer, and W. Gujer. 2009. Closing the capability gap: strategic planning for the infrastructure sector. California Management Review 51 (2):30-50. http://dx.doi.org/10.2307/41166479

Dreborg, K. H. 2006. Essence of backcasting. Futures 28 (9):813-828. http://dx.doi.org/10.1016/S0016-3287(96)00044-4

Elzen, B., and A. Wieczorek. 2005. Transitions towards sustainability through system innovation. Technological Forecasting and Social Change 72(6):651-661. http://dx.doi. org/10.1016/j.techfore.2005.04.002

Farla, J., J. Markard, R. Raven, and L. Coenen. 2012. Sustainability transitions in the making: a closer look at actors, strategies and resources. Technological Forecasting and Social Change 79:991-998. http://dx.doi.org/10.1016/j. techfore.2012.02.001 
Farrelly, M., and R. Brown. 2011. Rethinking urban water management: experimentation as a way forward? Global Environmental Change 21(2):721-732. http://dx.doi.org/10.1016/ j.gloenvcha.2011.01.007

Ferguson, B. C., R. R. Brown, and A. Deletic. 2013. Diagnosing transformative change in urban water systems: theories and frameworks. Global Environmental Change 23 (1):264-280. http://dx.doi.org/10.1016/j.gloenvcha.2012.07.008

Folke, C. 2006. Resilience: the emergence of a perspective for social-ecological systems analyses. Global Environmental Change 16(3):253-267. http://dx.doi.org/10.1016/j. gloenvcha.2006.04.002

Foxon, T. J., M. S. Reed, and L. C. Stringer. 2009. Governing long-term social-ecological change: what can the adaptive management and transition management approaches learn from each other? Environmental Policy and Governance 19 (1):3-20. http://dx.doi.org/10.1002/eet.496

Frantzeskaki, N., and D. Loorbach. 2010. Towards governing infrasystem transitions: reinforcing lock-in or facilitating change? Technological Forecasting and Social Change 77:1292-1301. http://dx.doi.org/10.1016/j.techfore.2010.05.004

Geels, F. W. 2002. Technological transitions as evolutionary reconfiguration processes: a multi-level perspective and a case-study. Research Policy 31(8-9):1257-1274. http://dx.doi. org/10.1016/S0048-7333(02)00062-8

Geels, F. W. 2004. From sectoral systems of innovation to socio-technical systems: insights about dynamics and change from sociology and institutional theory. Research Policy 33 (6-7):897-920. http://dx.doi.org/10.1016/j.respol.2004.01.015

Geels, F. W., and J. Schot. 2007. Typology of sociotechnical transition pathways. Research Policy 36(3):399-417. http:// dx.doi.org/10.1016/j.respol.2007.01.003

Genus, A., and A.-M. Coles. 2008. Rethinking the multi-level perspective of technological transitions. Research Policy 37 (9):1436-1445. http://dx.doi.org/10.1016/j.respol.2008.05.006

Giddens, A. 1984. The constitution of society: outline of the theory of structuration. University of California Press, Berkeley, California, USA.

Gunderson, L. H., and C. S. Holling, editors. 2002. Panarchy: understanding transformations in human and natural systems. Island, Washington, D.C., USA.

Gunderson, L. H., C. S. Holling, and G. D. Peterson. 2002. Surprises and sustainability: cycles of renewal in the Everglades. Pages 315-332 in L. H. Gunderson and C. S. Holling, editors. Panarchy: understanding transformations in human and natural systems. Island, Washington, D.C., USA.
Holling, C. S. 1973. Resilience and stability of ecological systems. Annual Review of Ecology and Systematics 4:1-23. http://dx.doi.org/10.1146/annurev.es.04.110173.000245

Holling, C. S., and L. H. Gunderson. 2002. Resilience and adaptive cycles. Pages 25-62 in L. H. Gunderson and C. S. Holling, editors. Panarchy: understanding transformations in human and natural systems. Island, Washington, D.C., USA.

Jefferies, C., and A. Duffy. 2011. The SWITCH transition manual. University of Abertay Dundee, Dundee, UK.

Lawrence, T. B., and R. Suddaby. 2006. Institutions and institutional work. Pages 215-254 in S. R. Clegg, C. Hardy, T. B. Lawrence, and W. R. Nord, editors. The Sage handbook of organizational studies. Sage, Thousand Oaks, California, USA.

Lawrence, T. B., R. Suddaby, and B. Leca. 2009. Institutional work: actors and agency in institutional studies of organizations. Cambridge University Press, Cambridge, UK. http://dx.doi.org/10.1017/CBO9780511596605

Lawrence, T., R. Suddaby, and B. Leca. 2011. Institutional work: refocusing institutional studies of organizations. Journal of Management Inquiry 20(1):52-58. http://dx.doi. org/10.1177/1056492610387222

Olsson, P., L. H. Gunderson, S. R. Carpenter, P. Ryan, L. Lebel, C. Folke, and C. S. Holling. 2006. Shooting the rapids: navigating transitions to adaptive governance of socialecological systems. Ecology and Society 11(1): 18. [online] URL: http://www.ecologyandsociety.org/vol11/iss1/art18

Ostrom, E. 2007. A diagnostic approach for going beyond panaceas. Proceedings of the National Academy of Sciences of the United States of America 104(39):15181-15187. http:// dx.doi.org/10.1073/pnas.0702288104

Ostrom, E. 2009. A general framework for analyzing sustainability of social-ecological systems. Science 325:419-422. http://dx.doi.org/10.1126/science.1172133

Pahl-Wostl, C. 2009. A conceptual framework for analysing adaptive capacity and multi-level learning processes in resource governance regimes. Global Environmental Change 19:354-365. http://dx.doi.org/10.1016/j.gloenvcha.2009.06.001

Pritchard, L. J., and S. E. Sanderson. 2002. The dynamics of political discourse in seeking sustainability. Pages 147-169 in L. H. Gunderson and C. S. Holling, editors. Panarchy: understanding transformations in human and natural systems. Island, Washington, D.C., USA.

Robinson, J., S. Burch, S. Talwar, M. O'Shea, and M. Walsh. 2011. Envisioning sustainability: recent progress in the use of participatory backcasting approaches for sustainability 
research. Technological Forecasting and Social Change 78:756-768. http://dx.doi.org/10.1016/j.techfore.2010.12.006

Roland, G. 2004. Understanding institutional change: fastmoving and slow-moving institutions. Studies in Comparative International Development 38(4):109-131. http://dx.doi. org/10.1007/BF02686330

Rotmans, J., R. Kemp, and M. van Asselt. 2001. More evolution than revolution: transition management in public policy. Foresight 3(1):15-31. http://dx.doi.org/10.1108/1463$\underline{6680110803003}$

Rotmans, J., and D. Loorbach. 2009. Complexity and transition management. Journal of Industrial Ecology 13 (2):184-196. http://dx.doi.org/10.1111/j.1530-9290.2009.00116. $\underline{\mathrm{X}}$

Roy, A. H., S. J. Wenger, T. D. Fletcher, C. J. Walsh, A. R. Ladson, W. D. Shuster, H. W. Thurston, and R. R. Brown. 2008. Impediments and solutions to sustainable, watershedscale urban stormwater management: lessons from Australia and the United States. Environmental Management 42:344-359. http://dx.doi.org/10.1007/s00267-008-9119-1

Scott, W. R. 2008. Institutions and organisations: ideas and interests. Third edition. Sage, Thousand Oaks, California, USA.

Shove, E., and G. Walker. 2007. Commentary: CAUTION! Transitions ahead: politics, practice, and sustainable transition management. Environment and Planning A 39:763-770. http:// $\underline{\text { dx.doi.org/10.1068/a39310 }}$

Smit, B., and J. Wandel. 2006. Adaptation, adaptive capacity and vulnerability. Global Environmental Change 16 (3):282-292. http://dx.doi.org/10.1016/j.gloenvcha.2006.03.008

Smith, A., and A. Stirling. 2010. The politics of socialecological resilience and sustainable socio-technical transitions. Ecology and Society 15(1): 11. [online] URL: http://www.ecologyandsociety.org/vol15/iss1/art11/

Smith, A., A. Stirling, and F. Berkhout. 2005. The governance of sustainable socio-technical transitions. Research Policy 34 (10):1491-1510. http://dx.doi.org/10.1016/j.respol.2005.07.005

Smith, A., J.-P. Voß, and J. Grin. 2010. Innovation studies and sustainability transitions: the allure of the multi-level perspective and its challenges. Research Policy 39:435-448. http://dx.doi.org/10.1016/j.respol.2010.01.023

Swart, R. J., P. Raskin, and J. Robinson. 2004. The problem of the future: sustainability science and scenario analysis. Global Environmental Change 14:137-146. http://dx.doi. org/10.1016/j.gloenvcha.2003.10.002
Truffer, B., E. Störmer, M. Maurer, and A. Ruef. 2010. Local strategic planning processes and sustainability transitions in infrastructure sectors. Environmental Policy and Governance 20(4):258-269. http://dx.doi.org/10.1002/eet.550

van de Meene, S. J., R. R. Brown, and M. A. Farrelly. 2011. Towards understanding governance for sustainable urban water management. Global Environmental Change 21 (3):1117-1127. http://dx.doi.org/10.1016/j.gloenvcha.2011.04.003

van der Brugge, R., and R. van Raak. 2007. Facing the adaptive management challenge: insights from transition management. Ecology and Society 12(2): 33. [online] URL: http://www. ecologyandsociety.org/vol12/iss2/art33/

Walker, B. H., L. H. Gunderson, A. P. Kinzig, C. Folke, S. R. Carpenter, and L. Schultz. 2006. A handful of heuristics and some propositions for understanding resilience in socialecological systems. Ecology and Society 11(1): 13. [online] URL: http://www.ecologyandsociety.org/vol11/iss1/art13

Ziegler, W. 1991. Envisioning the future. Futures 23 (5):516-527. http://dx.doi.org/10.1016/0016-3287(91)90099N 